Kaloper, S. E., Čadro, S., Uzunović, M., Cherni-Čadro, S. (2020): Determination of erosion intensity in Brka watershed, Bosnia and Herzegovina. Agriculture and Forestry, 66 (2): 79-92.

DOI: 10.17707/AgricultForest.66.2.08

\author{
Selman Edi KALOPER ${ }^{I}$, Sabrija ČADRO ${ }^{I}$, \\ Mirza UZUNOVIĆ ${ }^{l}$, Salwa CHERNI-ČADRO
}

\title{
DETERMINATION OF EROSION INTENSITY IN BRKA WATERSHED, BOSNIA AND HERZEGOVINA
}

\section{SUMMARY}

The Bosnia and Herzegovina $(\mathrm{BiH})$ erosion map was made in 1985 , however, over a period of 35 years, there has been a substantial change in the values of most erosion factors, resulting in the change of the erosion intensity. Changes relate to demographics, urbanization and land use as well as climate. The increase in temperature and the occurrence of extremes caused significant environmental and economic consequences (May 2014 floods). This situation is more pronounced in the northern part of the country, especially in the lower parts of the larger basins. Risk assessment procedures using modern software and hardware solutions can help decision-makers to recognize sites where forest should not be cut down, certain crops should not be grown or soil conversation measures are necessary. Therefore, the aim of this research is to estimate the intensity of erosion processes in one such watershed in $\mathrm{BiH}$ - the Brka watershed, taking into consideration current conditions and using modern hardware and software solutions. To calculate erosion intensity the Gavrilovic method supported with GIS techniques was used. The soil protection $(\mathrm{x})$, soil erodibility $(y)$ and type and extent of erosion $(\phi)$ coefficients were calculated using digital maps: CORINE 2018 (grid size $100 \mathrm{~m}$ x $100 \mathrm{~m}$ ) land cover, soil map of $\mathrm{BiH}$ and open-source satellite images. The slope was calculated from the $\mathrm{BiH}$ digital elevation model $(25 \mathrm{~m} \times 25 \mathrm{~m})$. The Brka watershed area $\left(184.09 \mathrm{~km}^{2}\right)$ was divided into four basins: Maočka Rijeka $\left(51.56 \mathrm{~km}^{2}\right)$, Rahička Rijeka (24.26 $\left.\mathrm{km}^{2}\right)$, Zovičica $\left(75.30 \mathrm{~km}^{2}\right)$ and direct basin of Brka $\left(32.94 \mathrm{~km}^{2}\right)$. The highest average erosion intensity was determined for Zovičica basin, where $\mathrm{Z}=0.56$. The calculated mean annual production of sediment per basin varies from 5,746 for Rahička Rijeka to $57,089 \mathrm{~m}^{3}$ year ${ }^{-1}$ for Zovičica, with total Brka river watershed sediment yield of $120,754 \mathrm{~m}^{3}$ year $^{-1}$.

Keywords: Gavrilovic method; Erosion intensity; Brka watershed; CORINE; GIS

\footnotetext{
${ }^{1}$ Sabrija Čadro (corresponding author: s.cadro@ppf.unsa.ba), Selman Edi Kaloper, Mirza Uzunović, University of Sarajevo, Sarajevo, BOSNIA AND HERZEGOVINA

${ }^{2}$ Salwa Cherni-Čadro, Hydro-Engineering Institute Sarajevo (HEIS), BOSNIA AND HERZEGOVINA

Paper presented at the GEA (Geo Eco-Eco Agro) International Conference 2020, Podgorica. Notes: The authors declare that they have no conflicts of interest. Authorship Form signed online. 


\section{INTRODUCTION}

Soil erosion has been considered as the primary cause of soil degradation and loss. Lately, erosion has become a growing problem when it comes to environmental and biodiversity protection in the Balkans (Spalevic et al., 2015). In Bosnia and Herzegovina $(\mathrm{BiH})$, soil erosion intensifies with the negative effects of man from the time of the ancient Illyrians, Romans, Slavs, etc. to this day. Logging and burning of forests and converting these areas to arable land resulted in the occurrence of excessive soil erosion (Šarić et al., 1999). Soil water erosion is one of the most important causes of soil degradation in $\mathrm{BiH}$, this is especially true for agricultural land and smallholder farms that are often located in marginal areas, where the soil quality is poor and the topography is complexed (J. Žurovec et al., 2017a). With its complex relief, geological and pedological structure, hydrography, precipitation regime and land use, $\mathrm{BiH}$ is highly vulnerable to destructive processes of erosion and floods, especially in the northern part of the country (Čadro et al., 2019; O. Žurovec et al., 2017b). According to Lazarević (1985b), as much as $83 \%$ of the total area of $\mathrm{BiH}$ is threatened by water erosion.

When it comes to the analysis of erosion processes in $\mathrm{BiH}$ in addition to local surveys at the parcel level (J. Žurovec \& Čadro, 2008; J. Žurovec et al., 2017a) the Gavrilovic method (Gavrilović, 1972) was used to map and analyze erosion at the larger-areas. An erosion map of the FR of Bosnia and Herzegovina was made in the period 1980-1985 (Lazarević, 1985b). Recently, in 2012 an erosion map of the Entity Republika Srpska in scale 1:25,000 (Radislav Tošić et al., 2012a; Radislav Tošić et al., 2012b) was made as well as in 2018 the erosion map of the Vrbas River Basin at a scale of 1:25,000 (Lovrić \& Tošić, 2018).

Latterly, there has been a substantial change in the values of most erosion factors, resulting in the change of erosion intensity. Changes relate to demographics, urbanization and land use as well as climate (Čadro et al., 2018; Čadro et al., 2019; Popov et al., 2018; Trbic et al., 2017; O. Žurovec et al., $2017 \mathrm{~b}$ ). The increase in temperature and the occurrence of extremes caused significant environmental and economic consequences (May 2014 floods). This situation is more pronounced in the northern part of the country, especially in the lower parts of the larger watersheds.

A map of the spatial distribution of the intensity of erosion processes should be the first step towards a better understanding of the situation in an area of a basin, as well as a more realistic view of the risks of natural disasters, especially erosion, floods and landslides. Such a map is essentially a measure for disaster risk reduction (DRR), a systematic approach to identifying, assessing and reducing the risks of disaster (Jamieson, 2016).

Therefore, the main objective of this study was to analyze the basic soil erosion factors and estimate the intensity of erosion processes in the River Brka watershed, taking into consideration current conditions and using modern hardware and software solutions. 
Study area and data collection

\section{MATERIAL AND METHODS}

The Brka River Basin is located in the northeast of $\mathrm{BiH}$, it covers the northern slopes of mountain Majevica and part of the Bosnian Posavina (Figure 1). The total watershed area is about $184.09 \mathrm{~km}^{2}$. The highest point is the Okresanica peak, 815 meters above sea level, while the lowest point is the delta of the Brka River at 84 meters above sea level. Most of the watershed area is located within the Brcko District, and only a small part to the south is in the Federation of Bosnia and Herzegovina (FBiH), the municipalities of Srebrenik and Čelić.

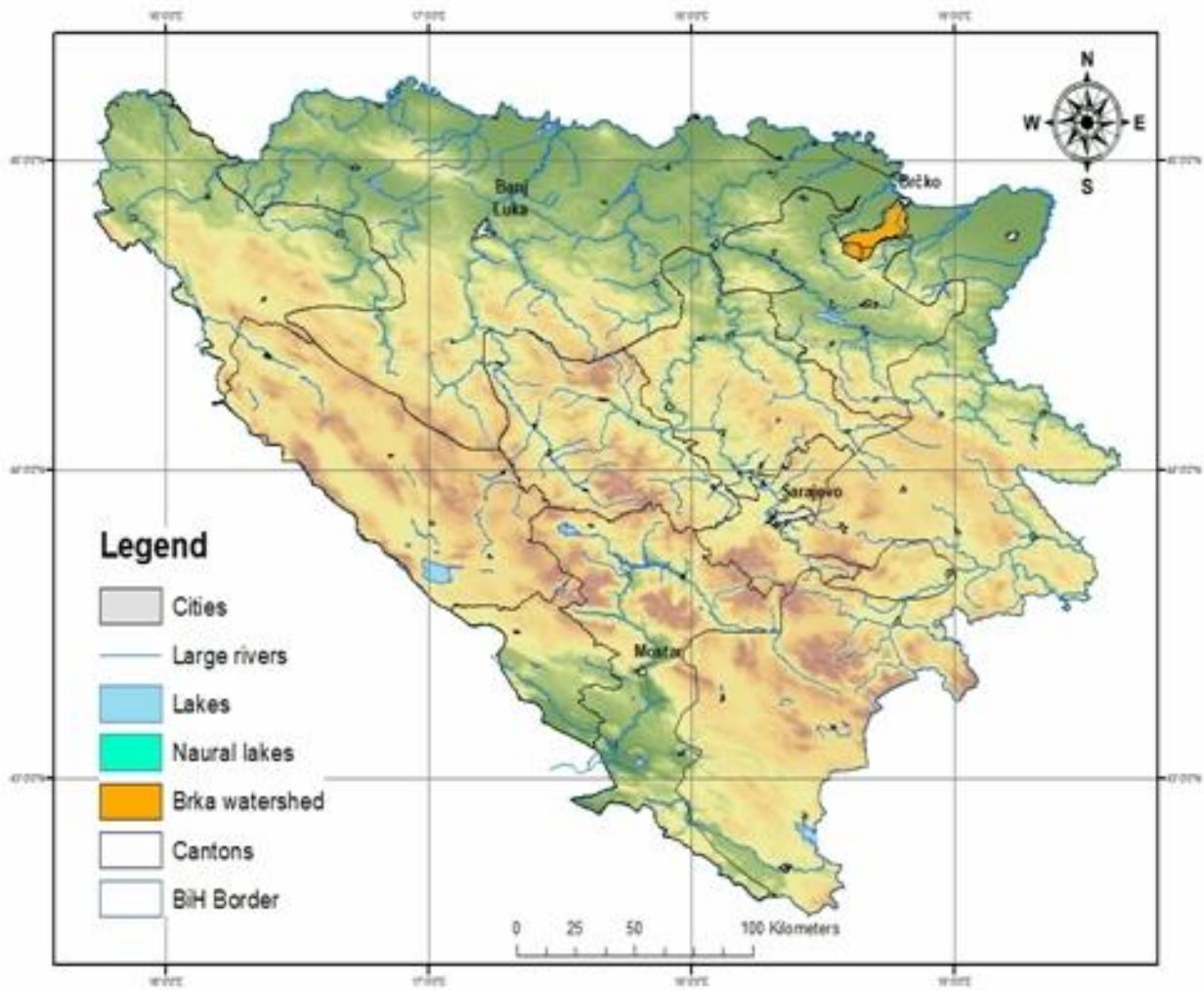

Figure 1. Geographical location, a digital elevation map of Bosnia and Herzegovina and location of Brka River watershed.

The Brka watershed belongs to the temperate continental climate zone. The characteristics of this climate are quite cold winters and warm summers. The average air temperature is $11.12^{\circ} \mathrm{C}$ and the average precipitation is $780 \mathrm{~mm}$ (Table 1). In the south, due to the increase in altitude, average temperatures are decreasing and precipitation is increasing (Majstorović, 2000). 
This is an area of great potential for the development of the economy, due to favorable population density, significant areas of arable land, developed road infrastructure and favorable position towards the three major regional centers, Belgrade, Zagreb and Sarajevo (Čardaklija, 2015; Smajlović, 2014).

Table 1. Average monthly climatic parameters from the Brčko weather station, period $1961-1990$.

\begin{tabular}{|c|c|c|c|c|c|c|c|c|c|c|c|c|c|}
\hline BRČKO & I & II & III & IV & V & VI & VII & VIII & IX & X & XI & XII & Ann. \\
\hline $\mathrm{T}_{\max }{ }^{1}$ & 2.8 & 6.3 & 12.0 & 17.5 & 22.5 & 25.4 & 27.5 & 27.4 & 23.5 & 17.8 & 10.4 & 5.2 & 16.52 \\
\hline $\mathrm{T}_{\text {mean }}{ }^{2}$ & -0.5 & 2.3 & 6.5 & 11.6 & 16.4 & 19.7 & 21.3 & 20.6 & 16.8 & 11.4 & 5.8 & 1.5 & 11.12 \\
\hline $\mathrm{T}_{\text {min }}{ }^{3}$ & -4.0 & -1.7 & 1.3 & 5.9 & 10.2 & 13.5 & 14.5 & 13.7 & 10.6 & 5.9 & 1.9 & -1.7 & 5.83 \\
\hline $\mathrm{RH}_{\text {mean }}{ }^{4}$ & 86 & 83 & 77 & 73 & 73 & 74 & 72 & 75 & 77 & 79 & 83 & 86 & 78 \\
\hline $\mathrm{u}_{(2)}{ }^{5}$ & 1.49 & 1.42 & 1.80 & 2.00 & 1.80 & 1.52 & 1.67 & 1.55 & 1.39 & 1.38 & 1.42 & 1.47 & 1.57 \\
\hline $\mathrm{PRCP}^{6}$ & 53 & 50 & 56 & 67 & 76 & 95 & 73 & 70 & 55 & 47 & 70 & 69 & 780 \\
\hline
\end{tabular}

Average air temperature; ${ }^{4} \mathrm{RH}_{\text {mean }}-$ Average relative humidity in $\% ;{ }^{5} \mathrm{u}_{(2)}$ - Average wind speed in $\mathrm{m} \mathrm{s}^{-1} ;{ }^{6} \mathrm{PRCP}-$ Average sum of precipitation in $\mathrm{mm}$.

\section{Erosion intensity calculation method}

In this research, the Gavrilovic method (Gavrilović, 1972) also known as the Erosion potential method (EPM) modified according to Lazarevic (1985a) and adapted for use in the geographical information system environment - GIS (N. Dragičević et al., 2013; Mustafić, 2012; Radislav Tošić \& Dragićević, 2012) was used to create maps and calculate erosion intensity $(Z)$, mean annual production of sediment (Wyear) and basin sediment yield (Gyear).

The Gavrilovic method has been used for over 40 years, both in our country (Lazarević, 1985b; Lovrić \& Tošić, 2018; Radislav Tošić et al., 2012a; Radislav Tošić et al., 2012b; Radoslav Tošić et al., 2019) and in the countries of the region Serbia (Dragićević et al., 2009; Kostadinov et al., 2012; Mustafić, 2012), Montenegro (Spalevic et al., 2017; Spalević et al., 2012), Croatia (Nevena Dragičević et al., 2016; Globevnik et al., 2003), Slovenia (Globevnik et al., 1998), Macedonia (Milevski et al., 2008), as well as around the world Italy (Ballio et al., 2010), Iran (Deilami et al., 2012; Spalević et al., 2016), Iraq (Ali et al., 2016), Chile (Kayimierski et al., 2013).

The soil erosion coefficient, or erosion intensity $(\mathrm{Z})$ was calculated using the analytical method with following equation:

Where:

$$
Z=Y \times X \times(\varphi+\sqrt{ }] s r)
$$

$Y$ - Coefficient of the resistance of the land to erosion (soil erodibility)

$X$-Coefficient of the protection of the land from the atmospheric impact, vegetation protection coefficient

$\varphi$ - Coefficient of the type of erosion

${ } J_{s r}$-Average slope (inclination) in $\%$ 
The quantitative values of the erosion coefficient $(Z)$ have been used to separate erosion intensity to 5 classes: Excessive erosion (I), $Z>1.00$; Intensive erosion, $Z=0.71-1.00$; Medium erosion (III), $Z=0.41-0.70$; Slight erosion (IV), $\mathrm{Z}=0.21-0.40$; Very slight erosion $(\mathrm{V}) . \mathrm{Z}=0.01-0.20$ (Lazarević, 1985a).

To calculate mean annual production of sediment per basin $-\mathrm{W}_{\text {year }}\left(\mathrm{m}^{3}\right.$ year $\left.{ }^{-1}\right)$ the following equations ware used:

$$
\begin{gathered}
T=\sqrt{\frac{\mathrm{t}}{10}+0.1} \\
W_{y e a r}=T \times H_{y e a r} \times \pi \times \sqrt{Z^{3}} \times F
\end{gathered}
$$

Where:

$\mathrm{T} \quad$ Temperature coefficient $\left({ }^{\circ} \mathrm{C}\right)$

$\mathrm{t} \quad$ Mean annual air temperature $\left({ }^{\circ} \mathrm{C}\right)$

$\mathrm{H}_{\text {year }} \quad$ Mean annual sum of precipitation (mm)

$\mathrm{F} \quad$ Area of the basin $\left(\mathrm{km}^{2}\right)$

Multiplying the mean annual production of sediment per basin $\left(\mathrm{W}_{\text {year }}\right)$ with Coefficient of the retention of sediment $\left(\mathrm{R}_{\mathrm{u}}\right)$ we calculated the mean annual volume of suspended and transported sediment per basin, or the basin sediment yield $-\mathrm{G}_{\text {year }}\left(\mathrm{m}^{-3}\right.$ year $\left.^{-1}\right)$. To do so the following equations were applied:

$$
\begin{gathered}
D_{d}=\frac{I_{p}+I_{a}}{F}=\frac{L}{F} \\
R_{u}=\frac{\sqrt{O \cdot D}}{\left(I_{p}+10\right)} \cdot D_{d} \\
G_{y e a r}=W_{y e a r} \cdot R_{u}
\end{gathered}
$$

Where:

$\mathrm{R}_{\mathrm{u}} \quad$ Coefficient of the retention of sediment

$\mathrm{O} \quad$ Basin perimeter $(\mathrm{km})$

D Average elevation difference of the basin $(\mathrm{km})$

$\mathrm{I}_{\mathrm{p}} \quad$ Length of the main watercourse $(\mathrm{km})$

$\mathrm{D}_{\mathrm{d}} \quad$ Density of the river network per basin $\left(\mathrm{km} \mathrm{km}^{-2}\right)$

$\mathrm{L} \quad$ Total length of basin watercourse $(\mathrm{km})$

$\mathrm{I}_{\mathrm{a}} \quad$ Length of the secondary watercourse $(\mathrm{km})$

The boundary of the basin area was determined using Digital terrain model (DEM: $25 \mathrm{~m} \mathrm{x} 25 \mathrm{~m}$ ) and Hydrographic network map of $\mathrm{BiH}$; the soil protection coefficient (X) from CORINE 2018 (grid size $100 \mathrm{~m}$ x $100 \mathrm{~m}$ ) land cover map based on the X values proposed by Globevnik et al. (2003). Soil erodibility (Y) was determined on the basis of the BiH soil map (scale 1: 50,000), while for the 
determination of type and extent of erosion $(\phi)$ coefficients open-source satellite images were used.

Esri ${ }^{\circledR}$ ArGIS 10.2.1 software was used to determine all required elements of the basin $\left({ } J_{s r}, \mathrm{~F}, \mathrm{O}, \mathrm{D}, \mathrm{I}_{\mathrm{p}}, \mathrm{D}_{\mathrm{d}}, \mathrm{L}\right.$ and $\left.\mathrm{I}_{\mathrm{a}}\right)$. The raster calculator tool was used to create $\mathrm{Z}$ and $\mathrm{W}_{\text {year }}$ maps.

Also, climate data from the Brčko weather station (period 1961 - 1990) was used to analyze the climatic conditions as well as the calculation of certain parameters within the EMP methods ( $\mathrm{T}$ and $\mathrm{H}_{\text {year }}$ ).

\section{RESULTS AND DISCUSSION}

Basic characteristics of the watershed and soil erosion factors

The Brka River watershed has an elongated shape and is characterized by a very small proportion of left tributaries, with almost all tributaries located on the right side of the Brka River. The total area of the Brka River watershed is 184.09 $\mathrm{km}^{2}$. However, for precise observation of the basic watershed characteristics as well as a more accurate calculation of erosion intensity ( $\mathrm{Z})$, the watershed area is divided into 4 separate sub-basins (Figure 2):

-Maočka River basin $\left(51.57 \mathrm{~km}^{2}\right)$,

-Rahička River basin $\left(24.27 \mathrm{~km}^{2}\right)$,

-Zovičica basin $\left(75.31 \mathrm{~km}^{2}\right)$, and

- Direct basin of the Brka river $\left(32.95 \mathrm{~km}^{2}\right)$

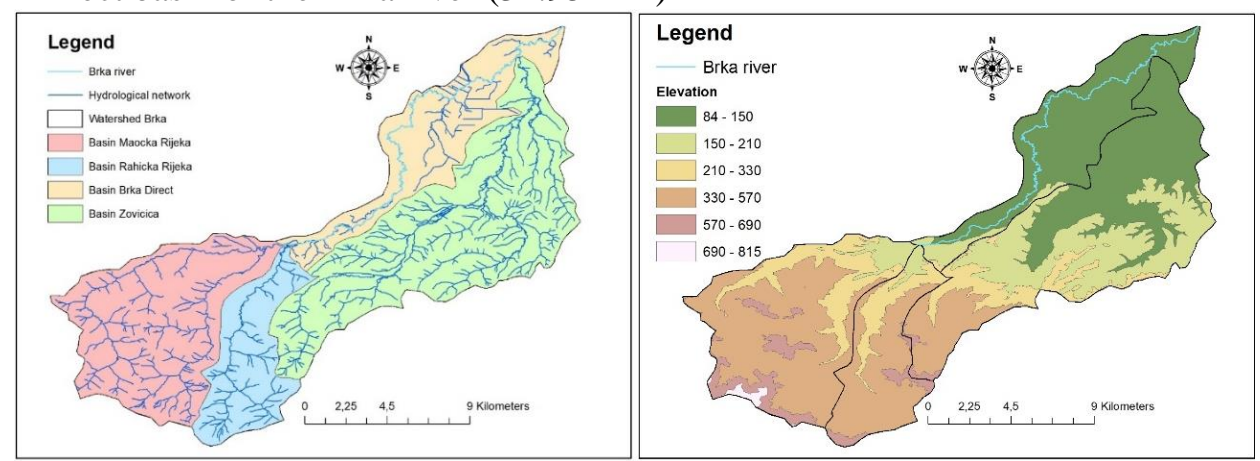

Figure 2. (a) Hydrological network and spatial distribution of the four Brka sub-basins; (b) Elevation map of Brka watershed.

The largest area is occupied by the Zovičica river basin, with about $41 \%$ of the total area, while the Rahička river basin occupies the smallest area or about $13 \%$ of the total watershed.

The direction of fall of the Brka River basin is southwest-northeast, which is the result of higher altitudes in the south ( 814 m.a.s.l.) that is, in the area of the Majevica Mountain and on the other side, low altitudes (84 m.a.s.l.) of the Posavina valleys in the north (Figure 2). The average basin elevation is $276 \mathrm{~m}$, with an almost equal proportion of lowlands with elevations up to $150 \mathrm{~m}(33 \%)$ and elevations ranging from 330 to $570 \mathrm{~m}(31 \%)$. Less than $5 \%$ of the watershed area is located at an altitude of more than $570 \mathrm{~m}$ (Table 2). 
Table 2. Share of different elevation categories for the Brka watershed.

\begin{tabular}{|l|c|c|}
\hline \multicolumn{1}{|c|}{ Elevation $(\mathrm{m})$} & Area $\left(\mathrm{km}^{2}\right)$ & Area $(\%)$ \\
\hline $84-150$ & 61.04 & 33.15 \\
\hline $150-210$ & 32.81 & 17.82 \\
\hline $210-330$ & 23.21 & 12.61 \\
\hline $330-570$ & 57.89 & 31.44 \\
\hline $570-690$ & 8.31 & 4.51 \\
\hline $690-814$ & 0.88 & 0.48 \\
\hline $84-814$ & 184.09 & 100.00 \\
\hline
\end{tabular}

An overview of the basic spatial and hydrological characteristics required for the EPM method calculation for the 4 defined sub-basins of the Brka River is given in Table 3.

Table 3. The river Brka sub-basin spatial and hydrological characteristics.

\begin{tabular}{|l|c|c|c|c|c|c|c|c|c|c|}
\hline Sub-basin & $\begin{array}{c}\mathrm{F}^{1} \\
\left(\mathrm{~km}^{2}\right)\end{array}$ & $\begin{array}{c}\mathrm{O} \\
(\mathrm{km})\end{array}$ & $\begin{array}{c}\mathrm{D}_{\max } \\
(\mathrm{km})\end{array}$ & $\begin{array}{c}\mathrm{D}_{\min } \\
(\mathrm{km})\end{array}$ & $\begin{array}{c}\mathrm{D} \\
(\mathrm{km})\end{array}$ & $\begin{array}{c}\mathrm{l}_{\mathrm{p}} \\
(\mathrm{km})\end{array}$ & $\begin{array}{c}\mathrm{l}_{\mathrm{a}} \\
(\mathrm{km})\end{array}$ & $\begin{array}{c}\mathrm{L} \\
(\mathrm{km})\end{array}$ & $\begin{array}{c}\mathrm{D}_{\mathrm{d}} \\
\left(\mathrm{km}^{-2}\right. \\
\mathrm{km}^{-2}\end{array}$ & $\mathrm{R}_{\mathrm{u}}$ \\
\hline $\begin{array}{l}\text { Maočka } \\
\text { R. }\end{array}$ & 51.57 & 34.15 & 0.81 & 0.15 & 0.66 & 12.48 & 97.26 & 109.74 & 2.12 & 0.45 \\
\hline $\begin{array}{l}\text { Rahička } \\
\text { R. }\end{array}$ & 24.27 & 28.42 & 0.69 & 0.15 & 0.54 & 13.93 & 37.97 & 51.90 & 2.13 & 0.35 \\
\hline Zovičica & 75.31 & 53.53 & 0.69 & 0.08 & 0.61 & 24.39 & 185.08 & 209.47 & 2.78 & 0.46 \\
\hline $\begin{array}{l}\text { Brka } \\
\text { direct }\end{array}$ & 32.95 & 44.34 & 0.27 & 0.08 & 0.18 & 26.57 & 48.45 & 75.03 & 2.27 & 0.18 \\
\hline Brka & 184.09 & 77.39 & 0.81 & 0.08 & 0.73 & 26.57 & 419.58 & 446.15 & 2.42 & 0.49 \\
\hline
\end{tabular}

${ }^{1} \mathrm{~F}$ - Area; $\mathrm{O}$ - Perimeter; $\mathrm{D}_{\max }$ - Maximum elevation; $\mathrm{D}_{\min }-$ Minimum elevation; $\mathrm{D}$ - Average elevation difference; $l_{p}$ - Length of the main watercourse; la - Length of the secondary watercourse, $L$ - Total length of basin watercourse; $D_{d}$ - Density of the river network per basin; $R_{u}$ Coefficient of the retention of sediment

The individual sub-basins are quite different, this is especially true for the Zovičica river basin, which occupies the largest surface area. The main watercourse, the river Brka is $26.57 \mathrm{~km}$ long. The Zovičica River is similar in length $(24.39 \mathrm{~km})$, however, the total length of its tributaries is more than 3 times greater. Also, the difference between the lowest and highest points of the Brka River is only $185 \mathrm{~m}$, unlike the Maočka River where this difference is $661 \mathrm{~m}$ or Zovičica where it is $611 \mathrm{~m}$. This situation results in high river network density $\left(D_{d}\right)$ as well as a significant retention coefficient $\left(R_{u}\right)$, which is especially true of the Zovičica River basin area.When it comes to soil type, the Dystric Kambisol occupies the largest area of the Brka watershed (Table 4). In most cases, this soil is covered with forest, but due to its favorable properties it is often used as agricultural land (Miljković, 2005; Resulović et al., 2008). Most of the areas 
under this type of soil are located in the southern part of the basin, respectively within the sub-basins of the Maočka and Rahiča rivers.

Table 4. Share of different soil types in the Brka watershed

\begin{tabular}{|l|c|c|}
\hline \multicolumn{1}{|c|}{ Soil type, BiH Nacional classification } & Area $\left(\mathrm{km}^{2}\right)$ & Area $(\%)$ \\
\hline Dystric Kambisol & 68.11 & 36.99 \\
\hline Pseudogley & 52.53 & 28.53 \\
\hline Luvisol & 29.75 & 16.16 \\
\hline Eutric Kambisol & 17.46 & 9.48 \\
\hline Humofluvisol & 13.06 & 7.09 \\
\hline Fluvisol & 1.98 & 1.08 \\
\hline Eugley & 1.25 & 0.68 \\
\hline
\end{tabular}

Pseudogley and Luvisol are in second and third place, respectively. These are heavy soils, with poor permeability and high erodibility (Dugalić \& Gajić, 2012; Resulović et al., 2008). These soils are very susceptible to erosion, especially if located on slopes greater than $12 \%$ (J. Žurovec, 2012). It is very important to note that these soils occupy $82 \mathrm{~km}^{2}$ or $45 \%$ of the Brka watershed. They are mainly located in the north part of the basin, at altitudes less than 330 $\mathrm{m}$.Based on the land use, the watershed can be divided into three zones, an urban zone in the far north that includes the city of Brčko itself, then an agricultural zone located in the middle part of the watershed, ie along the river Brka itself and within the Zovičica river basin. The third zone, the forest zone, is located in the south of the basin, that is, on the slopes of mountain Majevica, or sub-basins Maočka and Rahička Rijeka (Table 5).

Table 5. Share of different CORINE land use classes in the Brka watershed.

\begin{tabular}{|l|c|c|}
\hline \multicolumn{1}{|c|}{ Land use classes } & Area $\left(\mathrm{km}^{2}\right)$ & Area (\%) \\
\hline Discontinuous urban fabric & 9.94 & 5.40 \\
\hline Industrial or commercial units & 0.30 & 0.16 \\
\hline Non-irrigated arable land & 19.54 & 10.61 \\
\hline Fruit trees and berry plantations & 2.76 & 1.50 \\
\hline Complex cultivation patterns & 42.83 & 23.36 \\
\hline Land principally occupied by agriculture & 17.18 & 9.33 \\
\hline Broad-leaved forest & 89.22 & 48.45 \\
\hline Mixed forest & 0.43 & 0.24 \\
\hline Transitional woodland-shrub & 1.91 & 1.04 \\
\hline Water courses & 0.03 & 0.02 \\
\hline
\end{tabular}

Nearly half $(49 \%)$ of the watershed area is covered by forest vegetation, dominated by the broad-leaved forests. Agricultural production takes place at 82 $\mathrm{km}^{2}$.Based on mentioned soil erosion factors in the Brka watershed, first, the individual land use and soil type categories were assigned with the values of the coefficients $\mathrm{X}$ and $\mathrm{Y}$, then their spatial distribution was created in Esri ${ }^{\circledR}$ ArGIS 
10.2.1 software (Figure 3). In this process, using the DEM and open-source satiate images, a slope map, as well as an $\phi$ map, were created (Figure 3 ).
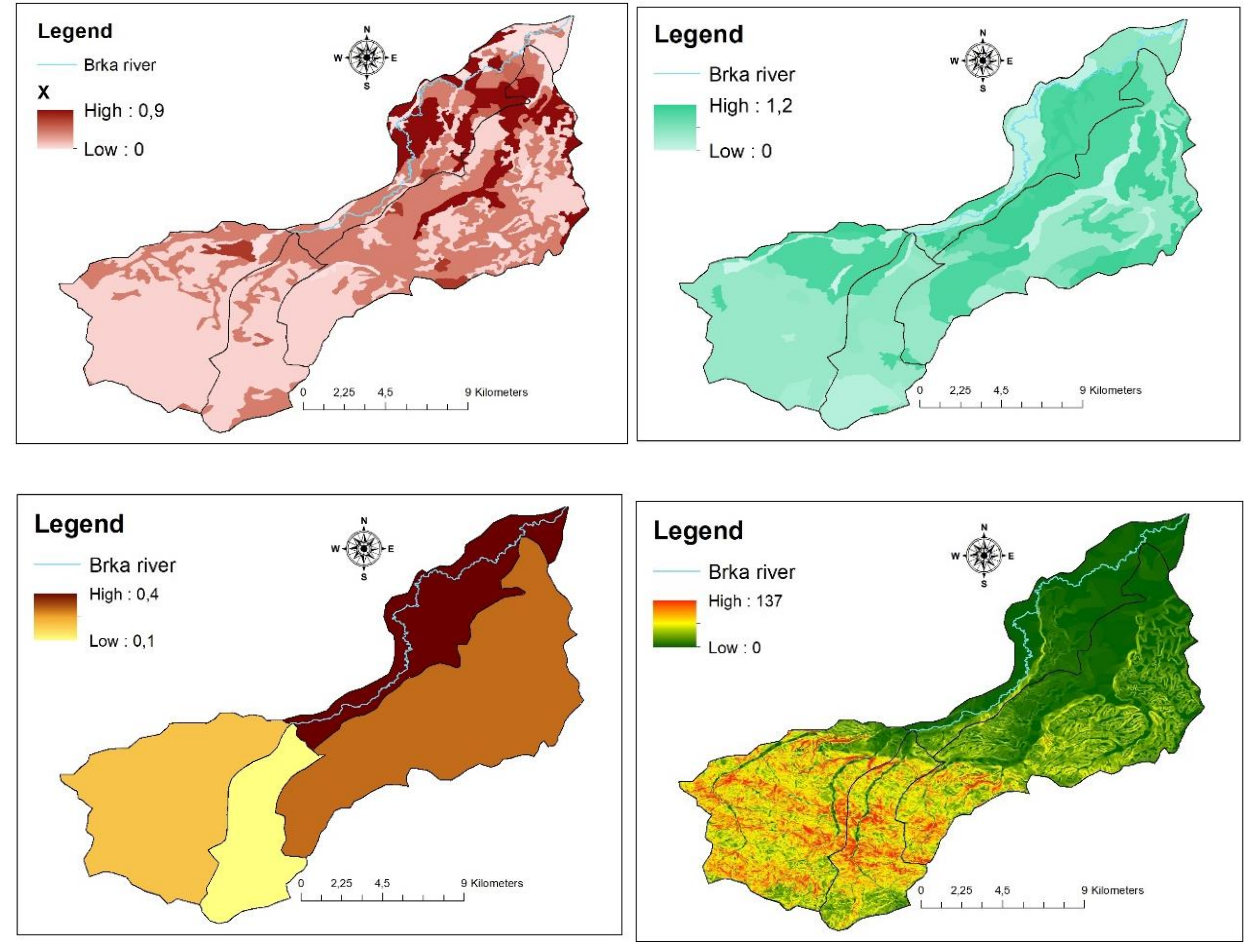

Figure 3. (a) Map of vegetation protection coefficient X; (b) Map of the resistance of the land to erosion, coefficient Y; (c) Map of the type of erosion coefficient $\phi$; (d) Slope map

Based on the erosion categories $16.68 \%$ of the territory is affected by excessive erosion, $7.24 \%$ by intensive erosion, $7.31 \%$ by medium erosion, $12.66 \%$ by slight erosion, $48.85 \%$ by very slight erosion, and $7.72 \%$ has no erosion (Table 6).

Table 6. Share of erosion intensity categories in the Brka watershed.

\begin{tabular}{|l|l|c|c|}
\hline Erosion category & Intensity of erosion & Basin area $\left(\mathrm{km}^{2}\right)$ & $\begin{array}{c}\text { Percentage of the } \\
\text { basin area (\%) }\end{array}$ \\
\hline- & No erosion & 13.37 & 7.27 \\
\hline V2 - V1 & Very slight erosion & 89.85 & 48.85 \\
\hline IV2 - IV1 & Slight erosion & 23.29 & 12.66 \\
\hline III2 - III1 & Medium erosion & 13.44 & 7.31 \\
\hline II2 - II1 & Intensive erosion & 13.68 & 7.24 \\
\hline I3 - I1 & Excessive erosion & 30.68 & 16.68 \\
\hline
\end{tabular}

In this way, all the maps necessary for the calculation (Equation 1) and spatial representation of the erosion intensity $(Z)$ were obtained. The next step 
was use of the Raster calculator tool to calculate and create erosion intensity ( $Z$ ) map of Brka watershed as shown in Figure 4.

The spatial distribution of erosion intensity (Figure 4) shows the highest intensity of erosion in the central part of the watershed. Although the upper part of the watershed has a higher slope, most of these areas are covered with forests, which very well protects the soil from erosion. This is not the case in the central and lower parts of the watershed, which are characterized by smaller slopes, but where intensive agricultural production is carried out on soils with poor waterphysical characteristics. This means that soil characteristics and land use have a dominant influence on the intensity of erosion processes in the Brka watershed.

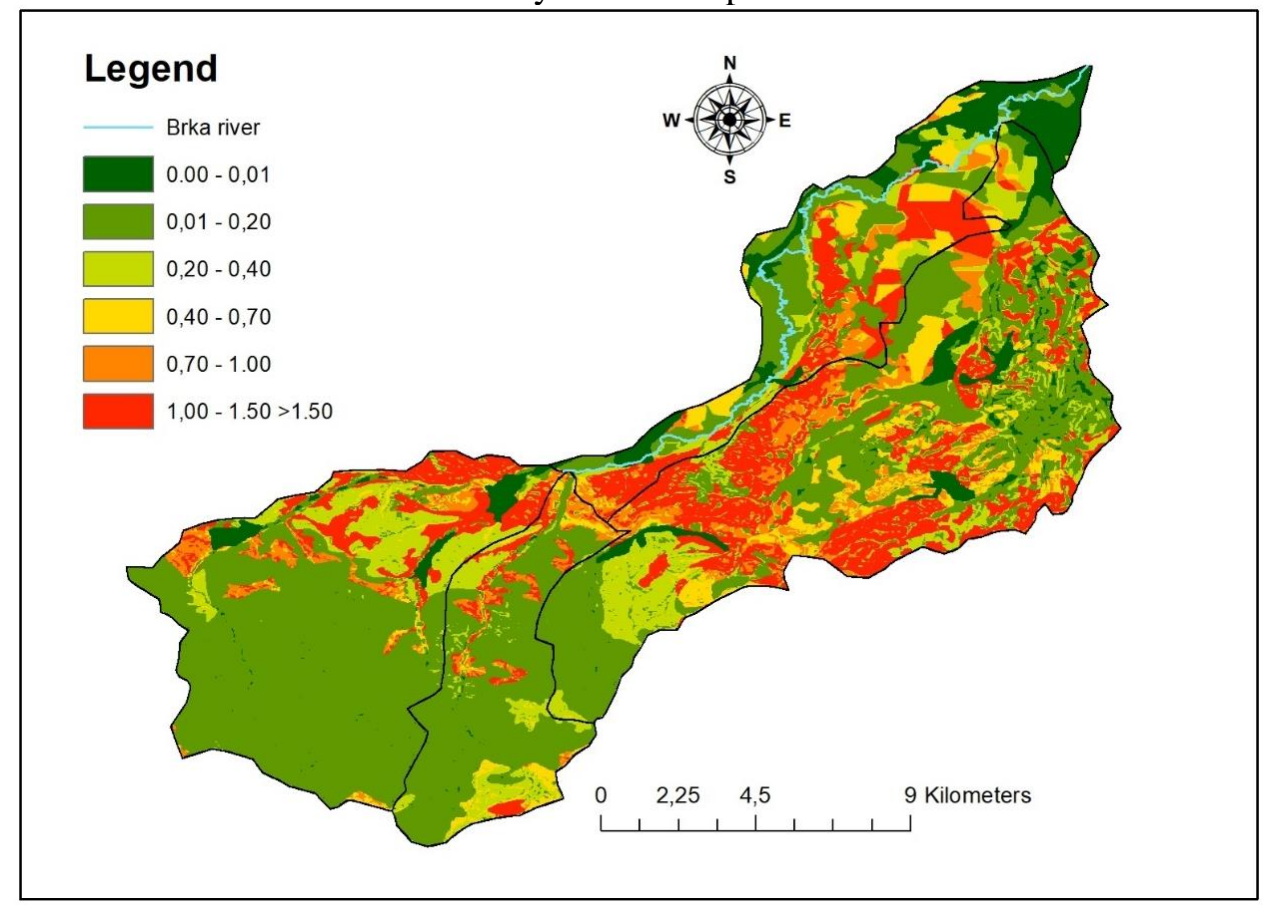

Figure 4. Erosion intensity (Z) map of the Brka watershed area

According to the results, the intensity of the erosion process in Brka watershed has a medium erosion character, with an average erosion coefficient of $Z=0.46$ (Table 7). In comparison, the average value of $Z$ for the Vrbas basin is much smaller $Z=0.18$ (Lovrić \& Tošić, 2018), as well as most of the other watersheds in BiH entity Republic of Srpska: Bosna $\mathrm{Z}=0.20$; Drina $=0.45$; Sana=0.15 (Radislav Tošić et al., 2012a). This indicates the pronounced erosion processes in the Brka watershed. This is especially true for the Zovičica River sub-basin $(Z=0.56)$ and the Brka River direct basin $(Z=0.46)$. This situation is probably the result of the high prevalence of high erodibility soils (Pseudogley and Luvisol) that are mostly used for agricultural production. 
Table 7. Summary of Gavrilovic method results for Brka watershed.

\begin{tabular}{|l|c|c|c|c|c|}
\hline \multicolumn{1}{|c|}{ Sub-basin } & $\mathrm{Z}^{1}$ & $\begin{array}{c}\text { Intensity of } \\
\text { erosion }\end{array}$ & $\begin{array}{c}\mathrm{W}_{\text {year }} \\
\left(\mathrm{m}^{3} \mathrm{year}^{-1}\right)\end{array}$ & $\begin{array}{c}\mathrm{W}_{\text {year }} \\
\left(\mathrm{m}^{3} \mathrm{year}^{-1} \mathrm{~km}^{-2}\right)\end{array}$ & $\begin{array}{c}\mathrm{G}_{\text {year }} \\
\left(\mathrm{m}^{3} \text { year }^{-1}\right)\end{array}$ \\
\hline $\begin{array}{l}\text { Maočka } \\
\text { Rijeka }\end{array}$ & 0.39 & Slight erosion & 58,810 & 1,140 & 26,442 \\
\hline $\begin{array}{l}\text { Rahička } \\
\text { Rijeka }\end{array}$ & 0.29 & Slight erosion & 16,331 & 672 & 5,746 \\
\hline Zovičica & 0.56 & Medium erosion & 123,459 & 1,639 & 57,089 \\
\hline Brka direct & 0.46 & Medium erosion & 43,820 & 1,329 & 7,818 \\
\hline Brka & 0.46 & Medium erosion & 242,421 & 1,316 & 120,754 \\
\hline
\end{tabular}

${ }^{1} \mathrm{Z}$ - Erosion intensity; $\mathrm{W}_{\text {year }}$ - mean annual production of sediment; $\mathrm{G}_{\text {year }}$ - basin sediment yield

The mean annual production of sediment per $\mathrm{km}^{2}\left(\mathrm{~W}_{\text {year }}\right)$ varied between 672 and $1639 \mathrm{~m}^{3}$ year ${ }^{-1} \mathrm{~km}^{-2}$. The calculated mean annual sediment yield $\left(\mathrm{G}_{\text {year }}\right)$ varies from 5,746 for Rahička Rijeka to 57,089 $\mathrm{m}^{3}$ year $^{-1}$ for Zovičica, with total Brka river watershed sediment yield of $120,754 \mathrm{~m}^{3}$ year $^{-1}$.

\section{CONCLUSIONS}

The average $Z$ value of 0.46 (medium erosion intensity), $43.89 \%$ of the territory threatened by water erosion, and $16.68 \%$ affected by excessive erosion indicates that at the Brka watershed certain soil conservation measures are more than necessary.The upper part of the watershed is covered with forest vegetation and therefore well protected from erosion processes. This is especially true for the sub-basins of the Maočka and Rahička rivers. Most of the agricultural production in this watershed takes place in the central part of the basin. However, this production takes place on soils with poor water-physical characteristics (Pseudogley and Luvisol). Since land use is an erosion factor that humans can control, it is necessary to act in this direction and prevent erosion conducting agro-technical and biological soil conservation measures.

In these circumstances, the cultivated soil should not be left bare - not sown at any cost, especially when it is plowed in the direction of the slope. Additionally, special attention should be paid to the length of parcels located on higher slopes. Contour soil cultivation and contour sowing/planting are recommended whenever the size and shape of the plot allow it.

\section{ACKNOWLEDGEMENTS}

The authors are very grateful to the Caritas Switzerland $(\mathrm{CaCH})$ in Bosnia and Herzegovina which founded the research as well as the hydrometeorological institutes in $\mathrm{BiH}$ for providing some of the datasets and Federal Institute for Agropedology, Sarajevo for providing soil map used in this used in this study.

\section{REFERENCES}

Ali, S. S., Al-Umary, F. A., Salar, S. G., Al-Ansari, N., \& Knutsson, S. (2016). GIS Based Soil Erosion Estimation Using EPM Method, Garmiyan Area, Kurdistan Region, Iraq. Journal of Civil Engineering and Architecture, 10, 291-308. doi: 10.17265/1934-7359/2016.03.004 
Ballio, F., Brambilla, D., Giorgetti, E., Longoni, L., Papini, M., \& Radice, A. (2010). Evaluation of sediment yield from valley slopes: a case study. Paper presented at the the Monitoring, Simulation, Prevention and Remediation of Dense and Debris Flows III, Milano, Italy.

Čadro, S., Miseckaite, O., Gavrić, T., Baublys, R., \& Žurovec, J. (2018). Impact of Climate Change on the Annual Water Balance in a Humid Climate Agriculture \& Forestry (Vol. 64, pp. 129-143). Podgorica.

Čadro, S., Uzunovic, M., Cherni-Čadro, S., \& Žurovec, J. (2019). Changes in the Water Balance of Bosnia and Herzegovina as a Result of Climate Change. Agriculture and Forestry, 65(3).

Čardaklija, H. (2015). Ekološki status rijeke Brke (neposredni sliv save). (Bsc), University in Sarajevo, Sarajevo.

Deilami, B. R., Sheikhi, M. L. A., Al-Saffar, M. R. A., \& Barati, V. (2012). Estimation of erosion and sedimentation in Karoon Basin using EPM with in geographic information system. Engineering science and technology: An International Journal, 2(5), 2250-3498.

Dragičević, N., Karleuša, B., \& Ožanić, N. (2013). GIS based monitoring database for Dubračina river catchment area as a tool for mitigation and prevention of flash flood and erosion. Paper presented at the The thirteenth International Symposium on Water Management and Hydraulic Engineering, Bratislava, Sovakia.

Dragičević, N., Karleuša, B., \& Ožanić, N. (2016). Erosion Potential Method (Gavrilović Method) Sensitivity Analysis. Soil \& Water Res. doi: doi: 10.17221/27/2016-SWR

Dragićević, S., Novković, I., \& Milutinović, M. (2009). The erosion intensity changes in Zaječar municipality. Bulletin of the Serbian geographical society, 89(4), 3-10.

Dugalić, G., \& Gajić, B. (2012). Pedologija. Čačak: Univerzitet u Kragujevcu, Agronomski fakultet u Čačku.

Gavrilović, S. (1972). Inženjering u bujičnim tokovima i eroziji. Beograd: Časopis "Izgradnja"

Globevnik, L., Holjevic, D., Petkovsek, G., \& Rubinic, J. (2003). Applicability of the Gavrilovic method in erosion calculation using spatial data manipulation techniques, erosion prediction in Ungauged Basins: integrating methods and techniques. Paper presented at the Symposium HS01, Sapporo.

Globevnik, L., Sovinc, A., \& Fazarinc, R. (1998). Land degradation and environmental changes in the Slovenian submediterranean (The Dragonja River Catchment). Geoökodynamik, XIX, 281-291.

Jamieson, T. (2016). Disastrous measures: Conceptualizing and measuring disaster risk reduction. International Journal of Disaster Risk Reduction, Volume 19(October 2016), Pages 399-412. doi: https://doi.org/10.1016/j.ijdrr.2016.09.010

Kayimierski, L. D., Irigoyen, M., Re, M., Menendey, A. N., Spalletti, P., \& Brea, J. D. (2013). Impact of climate change on sediment yield from the upper Plata basin. International Journal of River Basin Management, 11(4), 1-11. doi: http://dx.doi.org/10.1080/15715124.2013.82806

Kostadinov, S., Radić, B., Dragović, N., \& Todosaljević, M. (2012). Unknown soil erosion and the possibility of its control in the watershed of the water reservoir "Prvonek". Paper presented at the the 15th International Congress of ISCO.

Lazarević, R. (1985a). Novi postupak za određivanje koeficijenta erozije Erozija 12. Beograd: Društvo bujičara Jugoslavije. 
Lazarević, R. (1985b). Soil erosion map of Bosnia and Herzegovina in scale 1:25000 Final Report for 1985 year (pp. 2-43). Sarajevo: Institute for water management Sarajevo.

Lovrić, N., \& Tošić, R. (2018). Assessment of soil erosion and sediment yield using erosion potential method: Case study - Vrbas river basin $(\mathrm{B} \& \mathrm{H})$. Bulletin of the Serbian geographical society, 98(1). doi: https://doi.org/10.2298/GSGD180215002L

Majstorović, Ž. (2000). Studija klimatoloških karakteristika sjevernog oboda Majevice. Sarajevo: Federal Hidrometeorological Institute.

Milevski, I., Blinkov, I., \& Trendafilov, A. (2008). Soil erosion processes and modelling in the upper Bregalnica catchment. Paper presented at the the conference of the Danubial countries on the hydrological forecasting and hydrological bases of water management (XXIV), Bled, Slovenia.

Miljković, S. N. (2005). Meliorativna pedologija. Novi Sad, Srbija: Univerzitet u Novom Sadu, Poljoprivredni fakultet. Javno vodoprivredno preduzeće "Vode Vojvodine".

Mustafić, S. (2012). Geografski faktori kao determinante intenziteta erozije na primjeru sliva Nišave. (PhD), University of Belgrade, Belgrade.

Popov, T., Gnjato, S., Trbic, G., \& Ivanisevic, M. (2018). Recent Trends in Extreme Temperature Indices in Bosnia and Herzegovina. Carpathian Journal of Earth and Environmental Sciences, 13(1), 211-224. doi: 10.26471/cjees/2018/013/019

Resulović, H., Čustović, H., \& Čengić, I. (2008). Sistematika tla/zemljišta - Nastanak, svojstva i plodnost. Sarajevo: Univerzitet u Sarajevu, Poljoprivredno-prehrambeni Fakultet.

Smajlović, A. (2014). Fizičkogeografske karakteristike sliva rijeke Brke. (Master), University in Tuzla, Tuzla.

Spalevic, V., Barovic, G., Mitrovic, M., Hodzic, R., Mihajlovic, G., \& Frankl, A. (2015). Assessment of sediment yield using the Erosion Potential Method (EPM) in the Karlicica watershed of Montenegro. Paper presented at the International Conference on Soil, Tirana, Albania.

Spalevic, V., Lakicevic, M., Radanovic, D., Billi, P., Barovic, G., Vujacic, D., . . . Khaledi Darvishan, A. (2017). Ecological-Economic (Eco-Eco) Modelling in the River Basins of Mountainous Regions: Impact of Land Cover Changes on Sediment Yield in the Velicka Rijeka, Montenegro. Not Bot Horti Agrobo, 45(2), 602-610. doi: DOI:10.15835/nbha45210695

Spalević, V., Behzadfar, A., Tavares, A. S., Moteva, M., \& Tanaskovik, V. (2016). Soil loss estimation of s7-2 catchment of the shirindareh watershed, iran using the river basin model. AGROFOR - International Journal. doi: http://dx.doi.org/10.7251/AGRENG1601113S

Spalević, V., Moahoney, W., Djurovic, N., Uzen, N., \& Curović, M. (2012). Calculation of soil erosion intensity and maximum outflow from the Rovacki River Basin, Montenegro. Agriculture \& Forestry,, 58(3), 7-21.

Šarić, T., Beus, V., Gadžo, D., \& Đikić, M. (1999). Uništavanje i zaštita zemljišta. Sarajevo: Garmond.

Tošić, R., \& Dragićević, S. (2012). Methodology update for determination of the erosion coeffitient (Z). Bulletin of the Serbian geographical society, XCII(1), 11-26. doi: 10.2298/GSGD1201011T

Tošić, R., Dragićević, S., \& Lovrić, N. (2012a). Assessment of soil erosion and sediment yield changes using erosion potential method - Case study: Republic of Srpska BiH. Carpathian Journal of Earth and Environmental Sciences, 7(4), 147-154. 
Tošić, R., Dragićević, S., Zlatić, M., Todosiljević, M., \& Kostadinov, S. (2012b). The impact of socio-demographic changes on land use and soil erosion (case study: Ukrina River catchment). Geographical Reviews, 46, 69-78.

Tošić, R., Lovrić, N., \& Dragićević, S. (2019). Assessment of the impact of depopulation on soil erosion: case study - republika srpska (bosnia and herzegovina). Carpathian Journal of Earth and Environmental Sciences, 14(2), 505-518. doi: 10.26471/cjees/2019/014/099

Trbic, G., Popov, T., \& Gnjato, S. (2017). Analysis of air temperature trends in Bosnia and Herzegovina. Geographica Pannonica, 21(2), 68-84. doi: 10.18421/Gp21.0201

Žurovec, J. (2012). Melioracije $i$ uređenje poljoprivrednog zemljišta. Sarajevo: Univerzitet u Sarajevu, Poljoprivredno-prehrambeni fakultet.

Žurovec, J., \& Čadro, S. (2008). Erosion Risk on the Arable Soils on the Hill Area of Canton Sarajevo. Radovi Poljoprivrednog Fakulteta Univerziteta u Sarajevu, 59(2), 299-310.

Žurovec, J., Čadro, S., Sinanović, K., Husić, S., Šehić, D., \& Mrkulić, A. (2017a). Procjena erozije i moguće mjere konzervacije poljoprivrednog tla na području Željeznog Polja-Assessment of Erosion and Possible Conservation Measures of Agricultural Soil in the Area of Željezno Polje. Works of the Faculty of Agriculture and Food Sciences, University of Sarajevo, LXII(67/2), 299-311.

Žurovec, O., Čadro, S., \& Sitaula, B. K. (2017b). Quantitative Assessment of Vulnerability to Climate Change in Rural Municipalities of Bosnia and Herzegovina. Sustainability, 9(1208), 18. doi: 10.3390/su9071208 